Scientific Review - Engineering and Environmental Sciences (2020), 29 (3), 377-387

Sci. Rev. Eng. Env. Sci. (2020), 29 (3)

Przegląd Naukowy - Inżynieria i Kształtowanie Środowiska (2020), 29 (3), 377-387

Prz. Nauk. Inż. Kszt. Środ. (2020), 29 (3)

http://iks.pn.sggw.pl

DOI 10.22630/PNIKS.2020.29.3.32

Elżbieta RADZISZEWSKA-ZIELINA ${ }^{\mathbf{1}}$, Filip KURAJ ${ }^{2}$

${ }^{1}$ Cracow University of Technology, Faculty of Civil Engineering

${ }^{2}$ Graduate of the Cracow University of Technology

\title{
Transparent insulation materials market in Europe
}

Key words: survey studies, transparent insulation, market

\section{Introduction}

Over the years, the European Union's energy policy (Directive 2010/31/EU) has been applying increasingly restrictive requirements concerning thermal insulation in buildings. The environmental assessment of residential buildings includes, among others, the environmental load associated with energy consumption and the accompanying atmospheric pollution (Korentz \& Nowogońska, 2018). The selection of the appropriate thermal insulation system becomes a critical matter (Fedorczak-Cisak et al., 2019b; Fedorczak-Cisak et al., 2020) due to ecological awareness and the constantly rising costs of heating buildings with conventional energy (Radziszewska-Zielina \& Rumin, 2016; Romanska-Zapala et al., 2018; Kisilewicz, Fedorczak-Cisak $\&$ Barkanyi, 2019). As a result, solutions that utilise renewable energy sources are sought. These include systems that utilise transparent thermal insulation (Kerschberger, 1994; Buratti \& Moretti, 2011).

In Radziszewska-Zielina and Śladowski (2017a, 2017b), Fedorczak-Cisak et al. (2019a), it is suggested to analyse various alternatives of carrying out projects and the associated costs during the initial analysis of a project's feasibility. In Radziszewska-Zielina and Rumin (2016), it was proven that the profitability of a given project depends on the technical solutions used to complete it. Biolek and Hanák (2019) proposed a solution that can aid real estate developers in making decisions in selecting material solutions while accounting for life-cycle costs (LCC). The growing pressure to introduce sustainable building is linked with increasingly rigorous requirements as to the profitability of construction or renovation projects and the occupancy of buildings, in addition to decreasing their impact on the environment. An overview of structural and material solutions of building partitions that account for sustainable development was presented in 
Gicala and Sobotka (2017). Radziszewska-Zielina and Kania (2017), Radziszewska-Zielina, Kania and Śladowski (2018) pointed to a range of problems and difficulties in the selection of technologies with which to carry out construction projects. The specificity of cooperation, including communication during the carrying out of construction projects in Ukraine, Poland and Slovakia, was presented by Radziszewska-Zielina (2010, 2011). Communication, coordination and material quality control was presented in the context of client satisfaction with structural system quality by Blaževska-Stoilkovska, Hanák and Žileska-Pančovska (2015).

The subject matter of thermal insulation in buildings is an important and multi-aspect subject. Contrary to traditional thermal insulation systems, wherein thermal insulation is to minimise heat loss from the building's interior, transparent insulation also allows for generating energy from solar radiation. This is performed via the use of transparent materials that can be penetrated by sunlight and that retain high thermal insulation properties. The insulation system in question combines the properties of translucent materials (such as window glazing) which can be easily penetrated by shortwave radiation, with those of materials with high thermal insulation properties, such as mineral wool or polystyrene foam. The combination of these two opposing characteristics has created a partition with a solar radiation penetration rate of around $50 \%$ yet with a heat transfer coefficient that is often twice as high as coefficients for typical insulation materials used in construction. In the case of applying transparent insulation to a building's walls, it was possible to create a partition that allows for more heat gain than loss (Fig. 1).

We can obtain two types of partitions when using transparent insulation materials. These are:

- daylight walls - solar radiation enters the building's interiors directly, i.e. the partition is a layer that lets

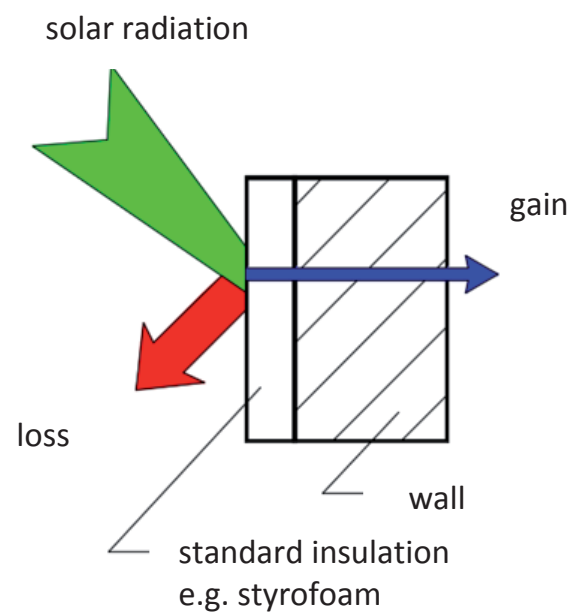

FIGURE 1. Illustration of heat balance for partitions with a typical (traditional) thermal insulation and transparent thermal insulation 
though solar radiation and natural light, which allows their absorption by internal partitions and furnishings, in addition to daylighting the interior using scattered light. The partition forms a system that allows direct heat and light gain;

- solid partitions - opaque partitions covered with a layer of transparent insulation. Solar radiation and daylight passes through the insulation layer and enters the accumulation or accumulation-collection layer, which absorbs the radiation energy and indirectly transfers the stream of heat inside. In this case, we are dealing with a system of indirect heat gains.

In both cases we are dealing with heat gain surpassing heat loss. Transparent insulation systems can be designed both for newly erected buildings and those that are to undergo energy retrofitting.

This article presents the transparent thermal insulation market as viewed by its manufacturers. The study was performed using a questionnaire. The authors also referred to the Polish domestic market in the study and its conclusions.

\section{Method and tools}

The objective of the study was to analyse the application of transparent thermal insulation in the European construction sector, determine the popularity of various technologies and materials used in their manufacturing, gauge the competition between transparent insulation manufacturers, and explore investment in the development of new transparent insulation technologies and trends in transparent insulation demand as reported by manufacturers.

The survey questionnaire prepared for the study was shared online through Google Forms in 2019. The research sample was determined via a list of transparent insulation manufacturers active on the European market, as presented by Ujma (2003) and the members of "Fachverband Transparente Wärmedämmung", a German organisation that connects research institutes and manufacturers who develop, produce and sell a range of transparent insulation products. The current member list can be found on the association's website (PATI, 2020). Some of the surveyed companies were featured on both lists. The final survey addressee list comprised twenty companies: fourteen from Germany, five from Switzerland and one from Austria. The respondents were largely composed of experts appointed to fill out the survey on behalf of their respective companies.

\section{Results}

The first question pertained to the popularity of direct and indirect heat gain systems. The use of transparent insulation in direct heat gain systems was the most popular $(88.2 \%$ of respondents picked this solution). Transparent insulation manufacturers present on the European market were primarily oriented towards new development projects, mostly commercial or public ones, which typically use transparent facades with this system.

The next group of questions concerned the materials used in manufacturing transparent insulation, which 
materials had the largest share in manufacturing volume and whether there was ongoing research on implementing new or further developing existing materials.

The percentage share of materials used in the production of transparent insulation by respondents (Fig. 2) demonstrates that glass $(82.2 \%)$ and synthetic materials were used the most frequently.

The respondents largely indicated that they were working on improving their products at the time of filling out the survey. The greatest share of respondents declared they were working on improving their current products and on combining different transparent insula- tion systems. The group that aspired to finding new material solutions for their products was the smallest (Fig. 3).

It can be concluded that the current state of the art concerning available materials and their properties enables the pursuit of more advanced solutions and their application in transparent insulation systems, as systems based on new substances are currently being researched.

One of the problems under study was the scale of manufacturing ready-to-use transparent insulation products. To this end, the respondents were asked to report their yearly production volume of insulation products in square metres.

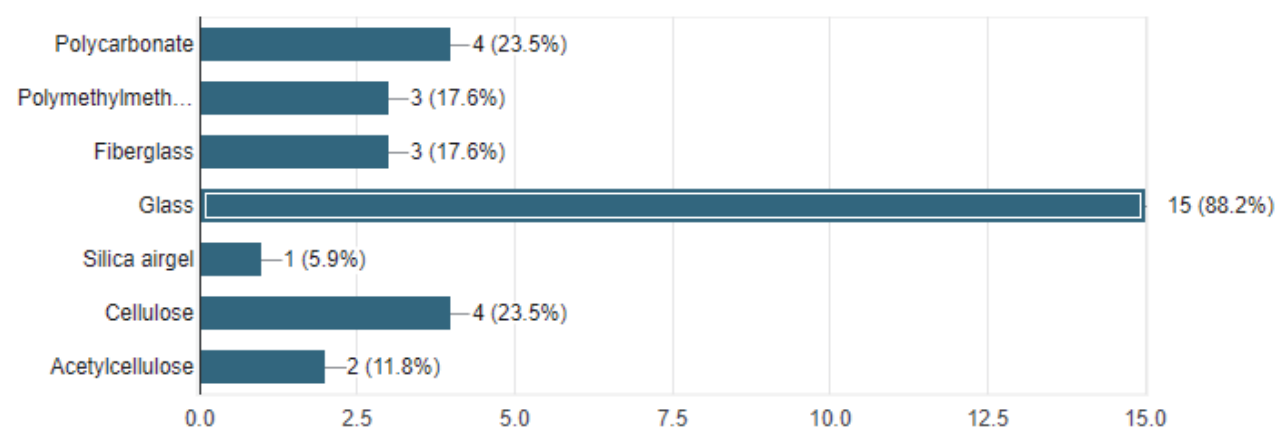

FIGURE 2. Types of materials used by respondents in transparent insulation manufacturing

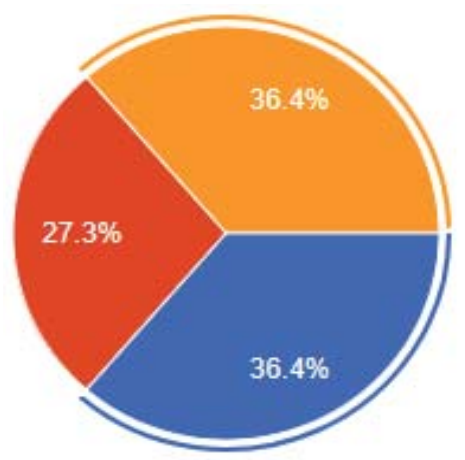

Improvement of the products currently produced

Searching for new material solutions

Combining different systems solutions

FIGURE 3. Structure of answers to the question concerning the method of applying improvements to products 
Almost half of the respondents $(47.1 \%)$ reported a yearly production volume exceeding $5,000 \mathrm{~m}^{2}$ of product (Fig. 4). Figure 5 describing the trend in yearly production rate demonstrates that nearly over a half of the respondents $(52.9 \%)$ reported a stable production rate, while around $40 \%$ reported a rise in production rate over the last couple of years. The remaining companies noted a decline in transparent insulation production rate.

Over half $(52.9 \%)$ of the respondents engaged in transparent insulation manufacturing only, while the remainder also offered the installation of finished insulation products, with the yearly volume of installed insulation reported as shown in Figure 6.

In summary, it can be concluded that there is demand for this type of insulation in Europe and this primarily applies to direct gain transparent insulation systems. The products of the companies who participated in the survey that are dedicated to the European market are largely complete systems that can be installed by construction companies with appropriately trained staff.

The majority of the respondents $(52.9 \%)$ rated the demand for transparent insulation in Europe as high, while 23.5\% rated it as low and a similar number of respondents found it hard to assess.
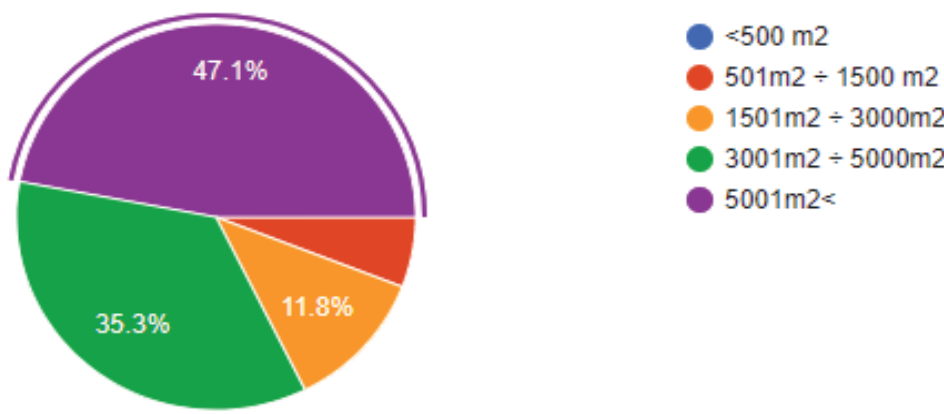

FIGURE 4. Structure of answers to the question concerning the yearly production rate of transparent insulation by surveyed companies
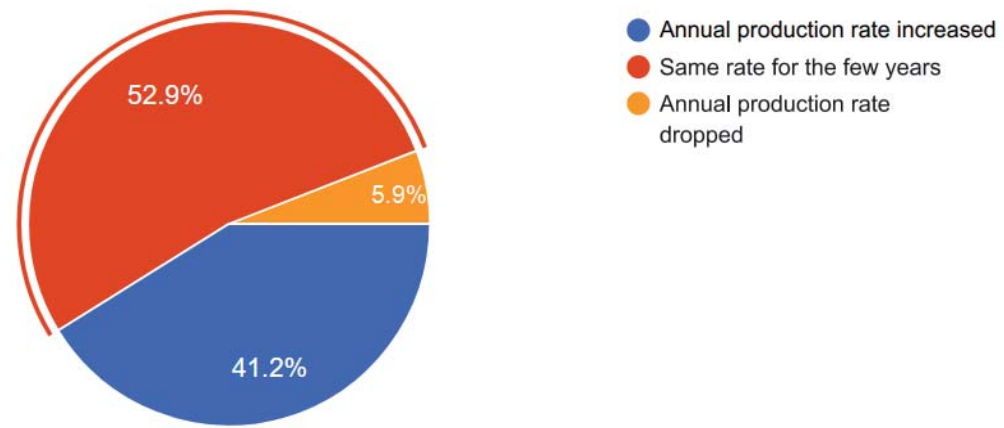

FIGURE 5. Trend in the yearly transparent insulation production rate among surveyed manufacturers 


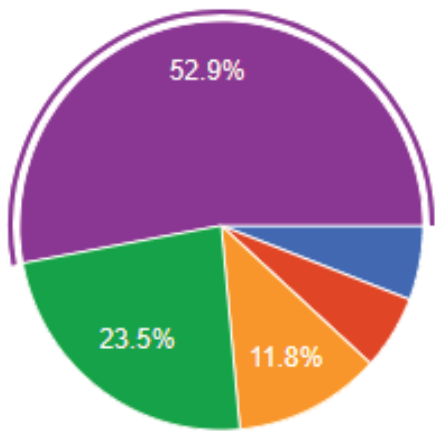

$<500 \mathrm{~m} 2$

$501 \mathrm{~m} 2 \div 1500 \mathrm{~m} 2$

$1501 \mathrm{~m} 2 \div 3000 \mathrm{~m} 2$

$3001 \mathrm{~m} 2 \div 5000 \mathrm{~m} 2$

without installation, production only

FIGURE 6. Yearly production rate of transparent insulation products reported by manufacturers

It was observed that the country with the largest amount of transparent insulation consumers in Europe was Germany (Fig. 7). All of the companies that took part in the survey reported they had completed at least one order from this country $(100 \%)$. Great Britain came second (47.1\%), while Austria, the Netherlands and Switzerland jointly came in third, with $41.2 \%$ each).
The respondents, when asked to identify the country where they had the most orders related to projects applying transparent insulation, pointed to Germany (94.1\%) and then to Switzerland (5.9\%). When listing the country their company was based in, most respondents reported Germany (82.4\% Germany, $11.8 \%$ Switzerland, 5.9\% Austria).

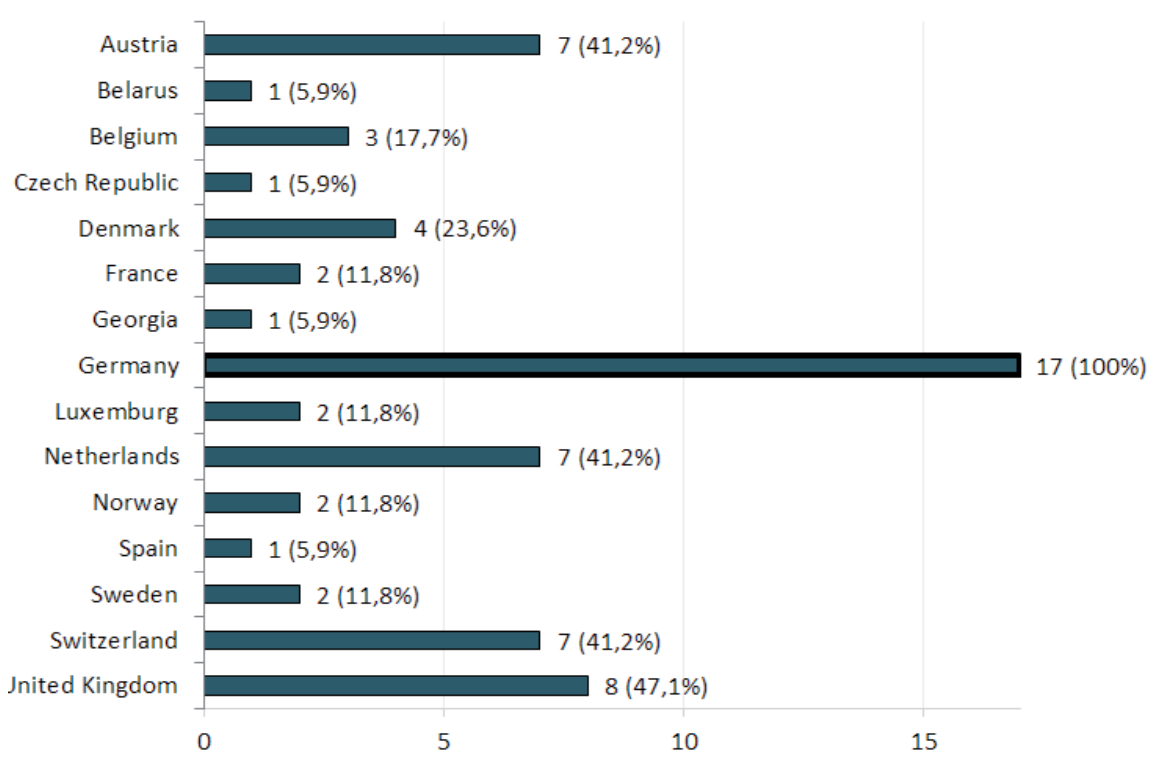

FIGURE 7. Countries in which respondents carried out projects involving transparent insulation 
Only one of the companies that took part in the survey had taken part in a construction project in Poland, while the vast majority declared they had no share in the Polish construction market. This was probably affected not only by the higher cost of transparent insulation, but also by difficulty in obtaining subsidies for applying solutions based on renewable energy in development projects. The developer must also go through periodical energy auditing procedures, monitor and document energy consumption data and the savings it brought (2016 Energy Performance Act). Another essential matter are the costs of administrative fees for submitting applications for subsidies, the cost of energy audits and applicable documentation, as well as defining whether the costs do not outweigh the benefits obtained via subsidy. According to a study performed by Go4Energy enterprise in 2014, representatives of the Polish construction sector (Augustyniak $\&$ Berezowski, 2014) saw the greatest barriers to energy-efficient buildings in, among others, the low accessibility to subsidies and the low amount of obtainable funds, the lack of a state-operated incentive system, high initial investment costs, complicated procedures and the long wait times associated with obtaining necessary approvals, the lack of political support for energy-efficient building or legislation which does very little to promote this branch of construction. Most respondents were of the opinion that Poland would not become a country where they would be likely to carry out projects and where transparent insulation would be used. Almost half of the respondents did not express a clear opinion on participating in projects in Poland, while only one company declared a willingness to do so. The subject of transparent insulation was discussed at length in Polish publications around ten years ago. There was also one transparent insulation system available on the market at the time. Interest in these solutions was so minuscule in recent years that it is no longer offered. Clients were mostly interested in solutions that had cheap initial investment costs, i.e. traditional thermal insulation systems employing mineral wool or styrofoam. In the opinion of the authors, transparent insulation systems were not presented sufficiently well to potential consumers in terms of their possible benefits.

The respondents, when asked whether they thought there was significant competition on the transparent insulation market, largely gave a negative answer (53\%), while $23.5 \%$ rated competition as significant and a similar number reported it was hard to assess. The respondents were then asked to report the number of companies with which they competed on the market. The results have been presented in Figure 8. As many as $47.1 \%$ of respondents declared they competed with 5-10 companies. It was observed that, in the respondents' opinion, the number of companies they competed with on the transparent insulation market was not high and that the companies that took part in the survey were not hindered in achieving their market goals.

Company representatives were asked to identify the period when their companies entered the transparent insulation market, as presented in Figure 9. Over $70 \%$ of the surveyed companies were present on the market for over 25 years. 


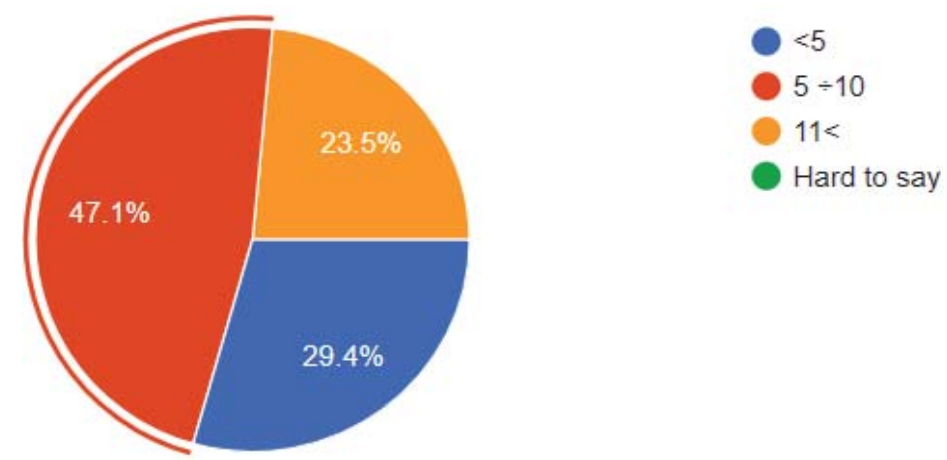

FIGURE 8. Structure of answers to the question concerning the number of companies the respondents competed with

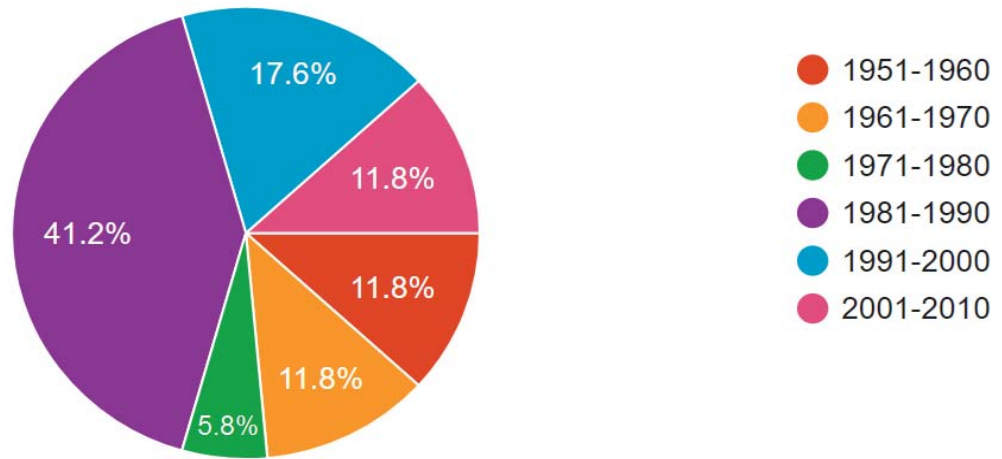

FIGURE 9. Period when the surveyed companies entered the transparent insulation market
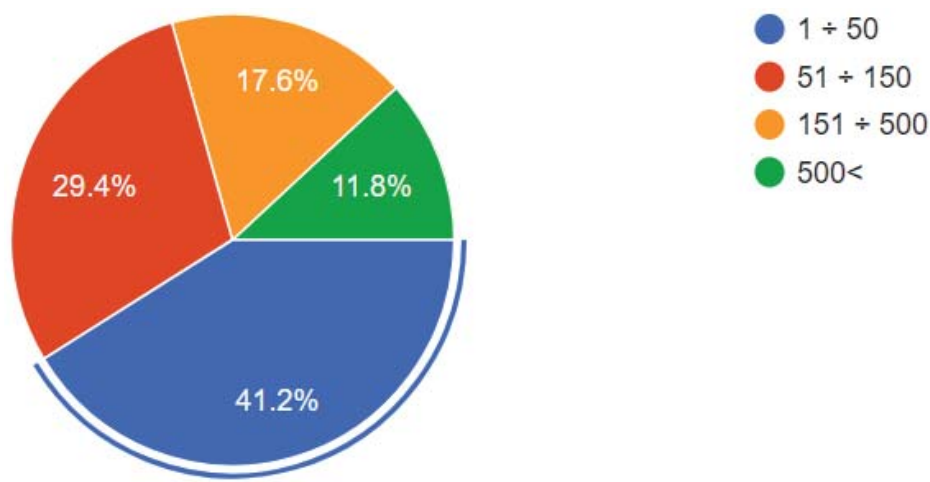

- $500<$

FIGURE 10. Company employee count 
Almost $60 \%$ of the companies who participated in the survey had an employee count of more than 50 (Fig. 10). Exactly $41.2 \%$ of companies employ up to 50 people. Small and medium-sized companies were predominant.

When analysing the information presented above, it can be concluded that the companies which participated in the survey had a confident market position, their many years of experience and employees counts were supported via regular orders, a stable reputation and sufficient demand present in the transparent insulation market in Europe.

The authors are aware that the study results presented herein are one-sided. To have a full picture of the transparent insulation market, one would have to study consumers, study the opinions of potential clients from various countries concerning transparent insulations, and analyse supply and demand. Studies of secondary sources and analyses of documents, reports, statistics and publications would also have to be performed. This will be explored in future studies.

\section{Conclusions}

The application of transparent insulation is associated with higher development costs, yet the potential return on investment in the form of savings during the occupancy stage can convince some developers to invest in it. The appearance of building facades after the application of transparent insulation is also attractive to clients.

Based on the presented survey results, it can be concluded that Europe successively increases its energy effectiveness, while the transparent insulation market can be considered to prosper. However, this prosperity is not equally distributed between countries, as indirect heat gain transparent insulation systems were viewed the most favourably in Germany. Great Britain came second, while Austria, the Netherlands and Switzerland jointly came in third.

Based on an observation of thermal insulation systems used in Poland, it can be observed that interest in transparent insulation is much lower there than in other European countries, particularly Western European ones. Most respondents were of the opinion that Poland would not become a country where they would be likely to carry out projects and where transparent insulation would be used. The main barriers include: an insufficient dissemination of knowledge concerning benefits derived from the use of transparent insulation, the high initial investment cost, potentially complicated assembly systems and a relatively long break-even period. Clients are mostly interested in solutions that have cheap initial investment costs, i.e. traditional thermal insulation systems employing mineral wool or styrofoam.

At present, further measures and programmes focusing on rational energy management are necessary, as developers could be motivated via a system of financial incentives, as well as the liberalisation of current procedures and requirement criteria for obtaining subsidies for newly-designed and modernised buildings. 


\section{References}

Augustyniak, T. \& Berezowski, M. (2014). Perspektywy rozwoju budownictwa energooszczędnego w Polsce [Prospects for the development of energy-saving construction in Poland]. Retrieved from: www.g4e.pl/ baza-wiedzy/raporty

Biolek, V. \& Hanák, T. (2019). LCC Estimation model: a construction material. Perspective Buildings, 9(8), 182. doi 10.3390/buildings 9080182

Blaževska-Stoilkovska, B., Hanák, T. \& Žileska-Pančovska, V. (2015). Materials supply management in construction projects and satisfaction with the quality of structures. Tehnicki Vjesnik, 22(3), 721-727.

Buratti, C. \& Moretti, E. (2011). Transparent insulating materials for buildings energy saving: experimental results and performance evaluation. In Third International Conference on Applied Energy. Perugia, 16-18 May 2011 (pp. 1421-1432). Perugia, Italy.

Directive 2010/31/EU of the European Parliament and of the Council of 19 May 2010 on the energy performance of buildings.

Fedorczak-Cisak, M., Kotowicz, A., Radziszewska-Zielina, E., Sroka, B., Tatara, T. \& Barnaś, K. (2020). Multi-criteria optimisation of the urban layout of an experimental complex of single-family NZEBs. Energies, 13(7), 1541. doi 10.3390/en13071541

Fedorczak-Cisak, M., Kowalska, A., Radziszewska-Zielina, E., Śladowski, G., Pachla, F. \& Tatara, T. (2019a). A multi-criteria approach for selecting the utility function of the historical building "Stara Polana" located in Zakopane. MATEC Web of Conferences, 262, 07002. doi 10.1051/matecconf/201926207002

Fedorczak-Cisak, M., Kowalska-Koczwara, A., Nering, K., Pachla, F., Radziszewska-Zielina, E., Śladowski, G., Tatara, T. \& Ziarko, B. (2019b). Evaluation of the criteria for selecting proposed variants of utility functions in the adaptation of historic regional architecture. Sustainability, 11(4), 1094. doi 10.3390/su11041094

Gicala, M. \& Sobotka, A. (2017). The analysis of construction and material solutions, taking into account the requirements of sustainable development. Scientific Review - Engineering and Environmental Sciences, 26(2), $159-170$.

Kerschberger, A. (1994). Transparente Wärmedämmung zur Gebäudeheizung. Systemausbildung, Wirtschaftlichkeit, Perspektiven [Transparent thermal insulation for heating buildings. System training, profitability, perspectives]. Bauök-Papiere, 56.

Kisilewicz, T., Fedorczak-Cisak, M. \& Barkanyi, T. (2019). Active thermal insulation as an element limiting heat loss through external walls. Energy and Buildings, 205, 109541. doi 10.1016/j.enbuild.2019.109541

Korentz, J. \& Nowogońska, B. (2018). Assessment of the life cycle of masonry walls in residential buildings. MATEC Web of Conferences, 174, 01025. doi 10.1051/matecconf $/ 201817401025$

Professional Association for Transparent Insulation [PATI] (2020). Members of Professional Association for Transparent Insulation. Retrieved from: http://www.umwelt-wand. de/ti/about/member.html

Radziszewska-Zielina, E. (2010). Analysis of the partnering relations of Polish, Slovak and Ukrainian construction enterprises. Technological and Economic Development of Economy, 16(3), 432-454.

Radziszewska-Zielina, E. (2011). Assessment methods of partnering relations of Polish, Slovak and Ukrainian construction enterprises with the use of fuzzy logic. Archives of Civil Engineering, 1(57), 87-118.

Radziszewska-Zielina, E. \& Kania, E. (2017). Problems in carrying out construction projects in large urban agglomerations on the example of the construction of the axis and High5ive Ooffice buildings in Krakow. MATEC Web of Conferences, 117, 00144. doi 10.1051/matecconf/201711700144

Radziszewska-Zielina, E. \& Rumin, R. (2016). Analysis of the profitability of investment in renewable energy sources on the example of a semi-detached house. E3S Web of Conferences, 10, 00079. doi 10.1051/e3sconf $/ 20161000079$

Radziszewska-Zielina,E.\& Śladowski, G.(2017a). Proposal of the use of a fuzzy stochastic network for the preliminary evaluation of the feasibility of the process of the adaptation of 
a historical building to a particular form of use. IOP Conference Series: Materials Science and Engineering, 245(7), 072029. doi $10.1088 / 1757-899 X / 245 / 7 / 072029$

Radziszewska-Zielina, E. \& Śladowski, G. (2017b). Supporting the selection of a variant of the adaptation of a historical building with the use of fuzzy modelling and structural analysis. Journal of Cultural Heritage, 26, 53-63.

Radziszewska-Zielina, E., Kania, E. \& Śladowski, G. (2018). Problems of the selection of construction technology for structures in the centres of urban agglomerations. Archives of Civil Engineering, 64(1), 55-71.

Romanska-Zapala, A., Bomberg, M., Fedorczak-Cisak, M., Furtak, M., Yarbrough, D. \& Dechnik, M. (2018). Buildings with environmental quality management. Part 2 : Integration of hydronic heating/cooling with thermal mass. Journal of Building Physics, 41(5), 397-417.

Ujma, A. (2003). Zasady i możliwości stosowania izolacji transparentnych [Principles and possibilities of using transparent insulation]. Izolacje, 8(1), 36-45.

Ustawa z dnia 20 maja 2016 r. o efektywności energetycznej. Dz.U. 2016 poz. 831 [Energy performance act of 20 May 2016. Journal of Laws 2016 item 831].

\section{Summary}

Transparent insulation materials market in Europe. This paper presents the European market of transparent insulation materials as viewed by manufacturers. The objective of the study was to analyse the application of transparent insulation materials in the construction sector across Europe, determine the popularity of various technologies and materials used to manufacture them, the competition among transparent insulation manufacturers, investment in the development of new transparent insulation technologies, and trends in demand for transparent insulation in Europe. The analysis was performed on the basis of a survey of manufacturers. The use of transparent insulation is associated with high cost, yet the potential return on investment in the form of savings over the course of a building's life-cycle convinces many potential developers to apply these materials. Based on the results of the survey, it can be concluded that European companies follow the increase in energy-efficiency and the transparent insulation market is prosperous, yet differs from country to country. It was observed that the positive perception of indirect heat gain transparent insulation systems was the most prevalent in Germany. The paper also explores the situation on the author's domestic market - the Polish transparent thermal insulation market.

\section{Authors' address:}

Elżbieta Radziszewska-Zielina (https://orcid.org/0000-0002-3237-4360)

Politechnika Krakowska im. Tadeusza Kościuszki

Wydział Inżynierii Lądowej

ul. Warszawska 24, 31-155 Kraków

Poland

e-mail: eradzisz@L7.pk.edu.pl 